\title{
ガス絶縁機器の急峻波サージ測定用 容量分圧センサの開発
}

$\begin{array}{llllll}\text { 正貝 } & \text { 島 } & \text { 政 } & \text { 史 } & \text { (電中研) } \\ \text { 正貝 } & \text { 藤 } & \text { 波 } & \text { 秀 } & \text { 雄 } & \text { (電中研) } \\ \text { 正貝 } & \text { 宅 } & \text { 間 } & & \text { 董 } & \text { (電中研) }\end{array}$

\author{
Capacitive Voltage Sensor for Measuring Very Fast \\ Transient Overvoltages in GIS \\ Masafumi Yashima, Member, Hideo Fujinami, Member, Tadasu Takuma, Member \\ (Central Research Institute of Electric Power Industry)
}

\begin{abstract}
A reliable technique is needed for accurate measurement of very fast transient overvoltages such as disconnector-induced surges occurring in GIS which have very steep front and high frequency oscillation. Recently, capacitive voltage sensors with very short response times have been proposed for this purpose. However, few studies have been made on the dielectric properties of materials used for a low-voltage-side capacitor, as well as frequency bandwidth of the measuring system.

In the present work, we propose a thin mica plate for a low-voltage-side capacitor which has a surface coated with silver on both sides. This material has been shown to have stable and high static capacitance up to a high frequency range. We also give a quantitative estimate for the frequency bandwidth of the measuring system. Furthermore, we have developed a practical-scale sensor of this type which can successfully measure simulated disconnector-induced surges of several hundred $\mathrm{kV}$ under similar conditions in GIS.
\end{abstract}

キーワード：ガス絶縁機器，急峻波サージ，測定，センサ，分圧器

\section{1.まえがき}

ガス絶縁開閉装置（GＩＳ）に代表されるガス絶縁機器 の基本構造は，中心導体の直径が比較的大きい同軸円筒 で, サージインピーダンスが小さい。そのため, 雷サージ の侵入や遮断アークの発生に伴って主回路を高速で伝搬す る進行波は減衰が小さい。また，GＩＳでは各種構成機器 がコンパクトに配置され，サージインピーダンスの不連続 点の間隔が小さいため, 進行波は多数回の反射を絽り返 し，それらが相互に重盢された複雑なサージ電圧がGＩS の各所に発生する。

G I S の過電圧の中で最も急峻なサージ電圧は断路器 サージと考えられており，その電圧立上り時間は数 ns 〜 数 $10 \mathrm{~ns}$, 電压振動周波数は数 $\mathrm{MHz} \sim$ 数 $10 \mathrm{MHz}$ と評価さ れている(1)(2)。近年, 断路器サージはGＩＳの絶縁レベル の低減によるコンパクト化推進のなかで, 雷サージに次ぐ 過電圧として注目されており，各種条件で絶縁特性が検討 されている(3) (6)。そのなかで断路器サージの測定手法も 重要な課題となっている。
GＩＳにおける急峻波サージ電圧を非接触で測定できる センサとして，静電容量結合を利用した各種の容量分圧七 ンサが提案されている(7) (13)。これらはセンサヘッドとな る浮遊電極とその対地容量（低電圧側容量）て構成され, 浮遊電極と中心導体との間のガス空間を高電圧側容量とし て利用するため，応答時間が極めて短いという特長を有す る。また，GＩＳの接地多ンク（シース）側にセンサを収 秋するスペースや開口部を設け，シース内面と同一面上に 浮遊電極を配置すれば，内部の電界分布に与える影響が小 さい上，センサ自体の絶縁問題を考慮する必要もない。こ のように，容量分圧センサはＧＩＳの急峻波サージ電圧の 測定器として理想的である。しかし，低電圧側容量に使用 される高分子フィルムなどの周波数特性について検討した 例は少なく，適切な材料の選定や測定系全体の周波数帯域 など，なお㭘討すべき点がある。

本論文では低電圧側容量に適する材料として，銀を焼付 けたマイカ板を提案するとともに, 測定系の入カインピー ダンスの条件と周波数帯域について評価した。さらに，実 規模の容量分圧センサを試作し, 数 $100 \mathrm{kV}$ の模擬断路器 
サージの測定に使用した。以下，これらについて報告す る。

\section{2. 実験裝置と手法}

く2・1> 同軸円筒モデルＧＩＳの母線を模籎した 同軸円筒モデルに容量分圧センサを取り付け，急峻な立上 りをもつステップ電压を入力して，センサの応答特性を検 討した。同軸円筒モデルは図 1 に示すように，中心導体 (外径 $60 \mathrm{~mm}$, 肉厚 $1.5 \mathrm{~mm}$ の黄銅パイプ) と接地シース (内径 $150 \mathrm{~mm}$, 肉厚 $5 \mathrm{~mm}$ のアルミパイプ) から構成され, シースには容量分圧センサを取り付けるための開口部（直 径 $50 \mathrm{~mm}$ ）が設けられている。中心導体はアクリル製の円 板により，2カ所で支持される。同軸円筒モデルの内部は 大気圧空気である。

同軸円筒モデルの片端には高周波同軸ケーブルを介して パルス発生器（三和電子SMP-1010A）を接続した。この とき, 接続ケーブルと同軸円筒モデルのサージインピーダ ンスを整合させるため, 中心導体,シースとも一定の直径 比を持つ円錐状の導入路を設けた。

この同軸円筒モデルに対し，過渡現象解析プログラム (EMTP: Electro-Magnet ic Transients Program) の ケーブル定数計算サブルーチン（Cable Constant）によ り,サージインピーダンスと進行波の伝搬速度を計算する と，それぞれ $54.9 \Omega ， 2.996 \times 10^{8} \mathrm{~m} / \mathrm{s}$ の值を得た。し たがって，パルス発生器から同軸円筒モデルに至るまで,

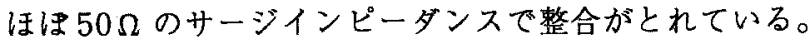

\section{く2・2〉＼cjkstart容量分圧センサの試作 図 2 に試作した容} 量分圧センサの構造を示す。センサヘッドとなる浮遊電極 (センサプレート) は直径 $44 \mathrm{~mm}$ のアルミ円板で, フラン ジ構造を持つアルミ接地ホルダにより, 誘電体（低電圧側 容量）を介して支持される。センサプレートと BNCコネク 夕を接続する同軸構造部の直径比は約 2.3 で, そのサージ インピーダンスがほは $50 \Omega$ となるようにした。低電圧側 容量には表 1 に示す 7 種類の高分子材料（PTFE：ポリテ トラフルオロエチレン, PI：ポリイミド, PET：ポリエチ レンテレフタレート) やマイカを使用した。表中の数值は BNC コネクタ端で実測した静電容量である。

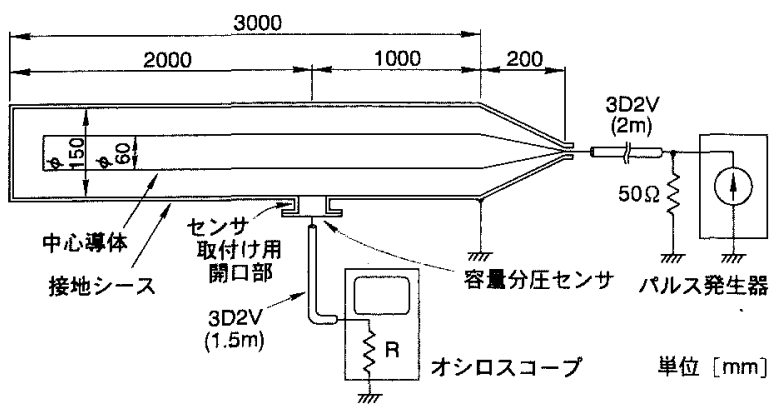

図 1 同軸円筒モデル

Fig. 1. Sketch of the co-axial model tested.
低電圧側容量の静電容量やその周波数特性は容量分圧七 ンサの応答特性に大きく影響するが，これについて検討し た例は少ない。これまでの提案例(8)（11)では厚さ20〜51 $\mu \mathrm{m}$ 高分子フィルムが多用されているが, このような薄 いフィルムは平面性が悪いため，センサプレートや接地ホ ルダとの密着性が問題となる。すなわち, 静電容量の小さ い空気層がフィルムと直列に入ると, 低電圧側容量の値的 材料固有の静䉓容量よりも小さい值になる。この点につい て，空気層の介在を容諗して静電容量を安定させる提案 $(8$ もあるが，G I Sではセンサが真空から数気圧までのガス 圧力にさらされること，ならびに長期間の安定性を考虑す ると, 空気層は排除すべきである。そこで, 表 1 の材料に はPTFEを除き，金属を片面または両面に蒸着して，静電 容量が材料固有の值に固定できるようにした。実際，銅を 両面に蒸着した厚さ $12 \mu \mathrm{m}$ の PET（No.6）の場合, 面 積と比誘電率から計算される静電容量は約 $3 \mathrm{nF}$ であるが, 実測值もこれと同程度であった。これに対し，片面のみ鉐 を蒸着したものは静電容量の実測値が計算値の半分程度も しくはそれ以下であった。

$<2 \cdot 3>$ 測定系 容量分圧センサの出力は高周波后 軸ケーブルを介してオシロスコープに入力した。測定系全 体の等価回路は図 3 のように表される。C 1 は中心導体上 センサプレート間の高電圧側容量で, 図 1 の配置に対し三 次元表面電荷法で求めた值は $0.22 \mathrm{pF}$ であった。 $\mathrm{C}_{2}$ は但 電圧側容量, $\mathrm{R}$ はオシロスコープの入力インピーダンスて ある。実験に使用したオシロスコープはソニーテクトロニ

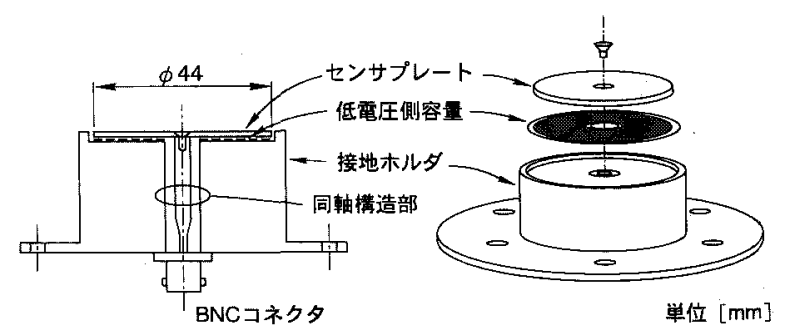

図 2 試作した容量分圧センサの構造 Fig. 2. Structure of the capacitive voltage sensor.

表 1 低電圧側容量に使用した誘電体材料 Table 1. Dielectric materials used for a lowvoltage-side capacitor.

\begin{tabular}{|c|c|c|c|}
\hline No. & $\begin{array}{c}\text { 低電压側容量材料 } \\
\text { (厚さ) }\end{array}$ & $\begin{array}{c}\text { 蒸着金属 } \\
\text { (愿着面, 膜厚) }\end{array}$ & $\begin{array}{l}\text { 静電容量 } \\
\text { の㬰測値 }\end{array}$ \\
\hline 1 & P TFE (1.0mm) & なし & $24.5 \mathrm{pF}$ \\
\hline 2 & $\mathrm{P}$ I $(50 \mu \mathrm{m})$ & 銅 (片面, $35 \mu \mathrm{m}$ ) & $0.47 \mathrm{nF}$ \\
\hline 3 & $\mathrm{PET}(25 \mu \mathrm{m})$ & 銅 (片面, $1.0 \mu \mathrm{m}$ ) & $0.84 \mathrm{nF}$ \\
\hline 4 & $\mathrm{PET}(5.5 \mu \mathrm{m})$ & 銅 (片面, $1.2 \mu \mathrm{m}$ ) & $1.73 \mathrm{nF}$ \\
\hline 5 & マイカ $(40 \mu \mathrm{m})$ & 銀燒付け (四面, $5 \mu \mathrm{m}$ ) & $2.85 \mathrm{nF}$ \\
\hline 6 & $\mathrm{PET}(12 \mu \mathrm{m})$ & 銅 (藏面, $1.2 \mu \mathrm{m}$ ) & $3.39 \mathrm{nF}$ \\
\hline 7 & $\mathrm{PET}(5 \mu \mathrm{m})$ & アルミ(雨面，250 $\AA$ ) & $6.80 \mathrm{nF}$ \\
\hline
\end{tabular}

PTFE：ポリテトラフルオロエチレン，PI ：ポリイミド, PET:ポリエチレシテレフタレート 
クス 7104 で, 垂直軸増幅器には7A29（入力インピーダ ンス $50 \Omega$ ，周波数帯域 $1 \mathrm{GHz}$ ）または $7 \mathrm{~A} 26$ （同 $1 \mathrm{M} \Omega$ ， $200 \mathrm{MHz}$ ) を使用した。

応答波形の特徽として次の 2 通りが考えられる。

（1） R が小さいか，または印加電圧の周波数が低い場 合：図 3 の等価回路は $C_{1}$ と $\mathrm{R}$ の直列回路となり, 出力は 印加電圧の微分波形となる。

（2） $\mathrm{R}$ が大きいか，または印加電圧の周波数が高い場 合：図 3 の等価回路は $C_{1}$ と $C_{2}$ の直列回路となり, 出力 は印加電圧に比例する。

図 3 の等価回路の低域遮断周波数は次式となる。

$$
f_{c}=\frac{1}{2 \pi R\left(C_{1}+C_{2}\right)}
$$

上式で例えば $\mathrm{R}=50 \Omega, \mathrm{C}_{1}=0.22 \mathrm{pF}, \mathrm{C}_{2}=1 \mathrm{nF}$ と すると $\mathrm{f}$ c は的 $3 \mathrm{MHz}$ となり，急峻波サージ電圧の立上り 部分は測定できても，雷インパルスの波尾など，電圧変化 のゆるやかな部分は測定できない。したがって，周波数帯 域の下限を下げるには RかC ${ }_{2}$ を大きくする必要がある。

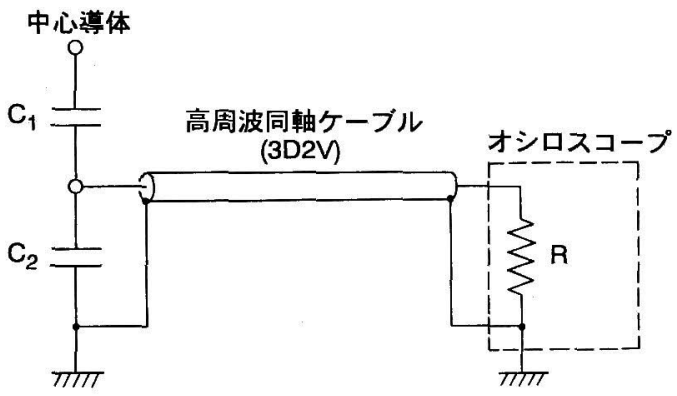

図 3 測定系の等価回路

Fig. 3. Equivalent circuit of the measuring system.

\section{3. ステップ電圧に対する応答特性}

$\langle 3 \cdot 1\rangle$ 容量分圧センサへの入力波形 同軸円筒 モデルの中心導体に入力される電圧波形を把握するため, 入力端に分岐を設けオシロスコープ（入カインピーダンス $50 \Omega$ ）により直接測定した。結果を図 4 に示す。電圧立上 り時間（全振幅の $10 \%$ から $90 \%$ まで立上るのに要する時 間）は $0.65 \mathrm{~ns}$ で，断路器サージの電圧立上りを模擬する のに充分急峻である（同図(a))。また，同軸円筒モデル の開放端で正反射された反射波が約 20ns 後に重畳されて, 階段状の波形になることも明確に観測できた（同図 (b))。 図 4 (c) は同一の条件に対して，EMTPで応答波形を解析し た結果で，実測值と良く一致している。容量分圧センサが 設置される場所は上記の入力端から約 $1.2 \mathrm{~m}$ 離れている ので，センサに入力される電圧波形は图 4 とは異なる。こ れを他の方法で測定することは困難であるので，EMTPに よる解析で図 5 の波形を得た。なお，図 4 (c)，図 5 の解 析例では, パルス発生器を電流源として扱い, 波高值 $20 \mathrm{~mA}$ のステップ電流を発生させている。 $\langle 3 \cdot 2\rangle$ 容量分圧センサの応答波形 表 1 に示し た 7 種類の低電圧側容量材料のうち, PTFE（No. 1 ），25 $\mu \mathrm{m}$ 厚 PET (No.3)，マイカ（No.5）に対する応答波 形の測定例を図 6 に示す。同軸円筒モデルに入力したステッ プ電圧の第 1 波の波高值は $321 \mathrm{~V}$ ，パルス幅は $1.0 \mu \mathrm{s}$ ，才

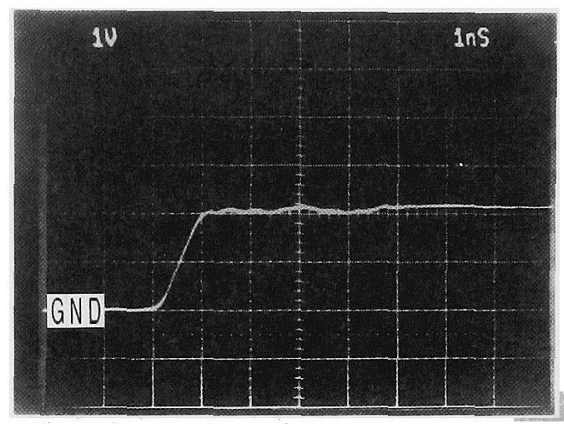

（a）電圧立上り部分（時間軸：1ns $/ \mathrm{div}$ )

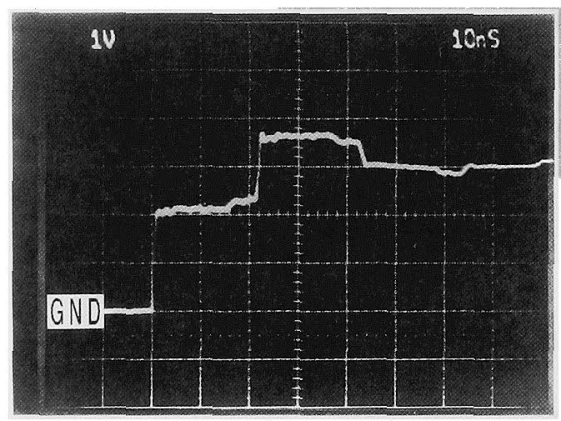

（b）波頭部分（時間軸：10ns/div）

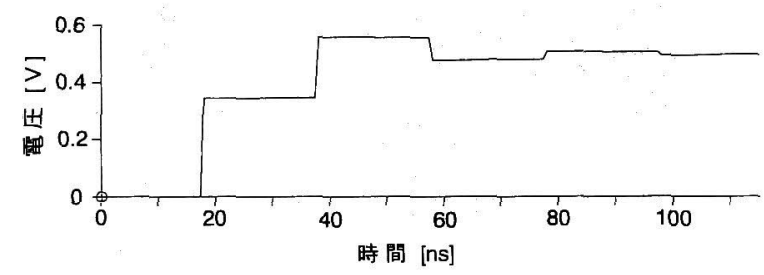

(c) EMTPによる解析波形

図 4 同軸円筒モデル入力端でのステップ電圧波形

Fig. 4. Step voltage waveform on the input terminal of the co-axial model.

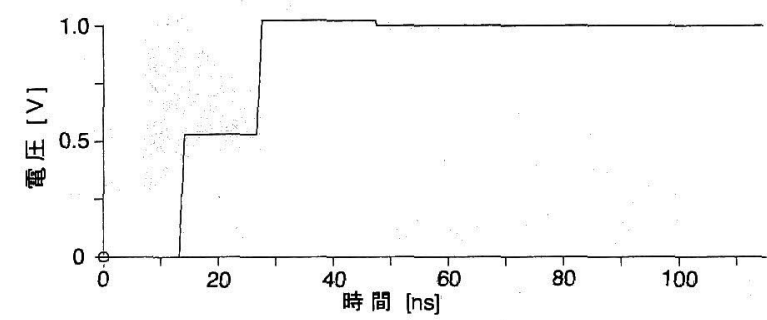

図 5 容量分压センサへの入力電圧波形 Fig. 5. Input voltage waveform at the capacitive voltage sensor. 
シロスコープの入カインピーダンスは $50 \Omega$ (周波数帯域： $1 \mathrm{GHz}$ ) である。

応答波形は各材料によって大いに異なり，静電容量が小 さい場合，もとの電圧波形の微分成分しか得られないが, 静電容量が大きくなるにつれてステップ電圧の平坦な部分 も現れるようになる。応答波形の立上り時間はいずれの材 料とも $0.65 \mathrm{~ns}$ と変わりがなく，入力電圧の立上りをその まま測定できた。

表 1 の各材料に対し, 分圧此の実測値と, ステップ電圧

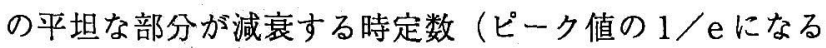
時間）を読み取り，表 2 に示す。減衰時定数は周波数帯域 の下限を評洒する数值である。また，EMTPによる解析か

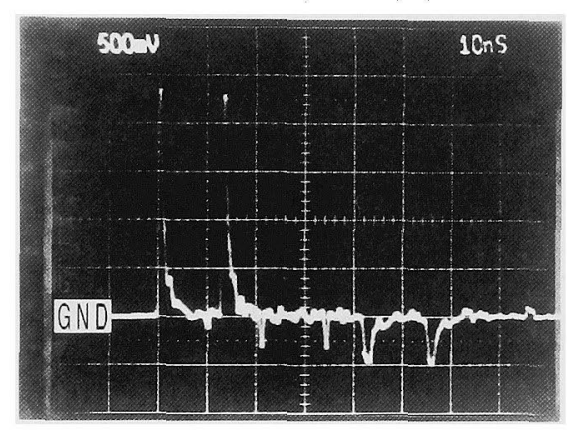

（a）低電圧側容量材料：PTFE

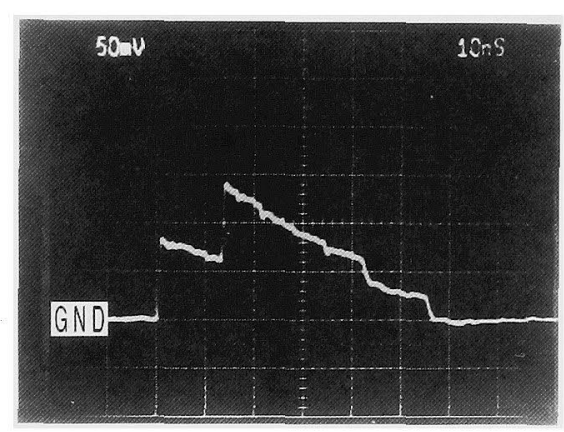

(b) 同: $\operatorname{PET}(25 \mu \mathrm{m})$

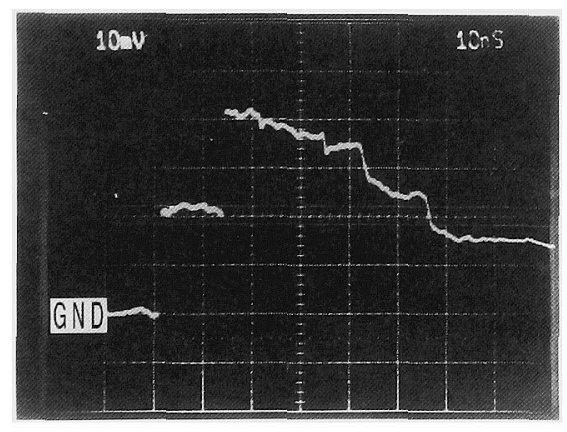

(c) 同：マイカ

図 6 容量分圧センサのステップ電圧に対する応 答波形（時間軸：10ns/div）

Fig. 6. Step response of the capacitive voltage sensor.
ら計算したこれらの値も併記した。この結果によれば，低 電圧側容量の静電容量が大きくなるにうれて分圧比が大き くなり, 減衰時定数は長くなる傾向が判る。しかし, 表 I の No. 1 No. 4 は減衰時定数が数 $10 \mathrm{~ns}$ 以下であるので, 使用不可能である。また, No. 7 は静電容量の実測値が最 大であるにもかかわらず，分圧比と減衰時定数は静電容量 が $1 \mathrm{nF}$ の材料と大差ない。この点については次節で考察 する。

表 2 ステップ電压印加時の分圧比と減衰時定数 Table 2. Voltage dividing ratio and decay time constant of measured voltage in step response.

\begin{tabular}{|c|c|c|c|c|c|}
\hline \multirow{2}{*}{ No. } & \multirow{2}{*}{$\begin{array}{c}\text { 低電圧側容量材料 } \\
\text { (厚さ) }\end{array}$} & \multicolumn{2}{|c|}{$\begin{array}{l}\text { ステップ電圧印加時 } \\
\text { の分压比 }\end{array}$} & \multicolumn{2}{|c|}{$\begin{array}{c}\text { 同 減衰時定数 } \\
\text { [ns] }\end{array}$} \\
\hline & & 実測値 & 計算値 & 実測值 & 計算值 \\
\hline 1 & P TFE $(1.0 \mathrm{~mm})$ & $1 / 140$ & $1 / 160$ & 1.1 & 1.2 \\
\hline 2 & P I $(50 \mu \mathrm{m})$ & $1 / 2100$ & $1 / 2170$ & 20 & 20 \\
\hline 3 & P E T $(25 \mu \mathrm{m})$ & $1 / 3900$ & $1 / 3870$ & 31 & 37 \\
\hline 4 & $\mathrm{PET}(5.5 \mu \mathrm{m})$ & $1 / 7700$ & $1 / 7810$ & 49 & 78 \\
\hline 5 & マイカ $(40 \mu \mathrm{m})$ & $1 / 14600$ & $1 / 13200$ & 99 & 135 \\
\hline 6 & P E T $(12 \mu \mathrm{m})$ & $1 / 15500$ & $1 / 15500$ & 101 & 160 \\
\hline 7 & $\mathrm{PET}(5 \mu \mathrm{m})$ & $1 / 4900$ & $1 / 31000$ & 13 & 325 \\
\hline
\end{tabular}

\section{4. 考察}

$<4 \cdot 1>$ 低電圧側容量の周波数特性容量分圧セ ンサの分圧比が広い周波数帯域にわたって一定であるため には，低電圧側容量が一定であることが前提となる。そこ で, 表 1 の 7 種類の材料に対して, 静電容量の周波数特性 を広帯域インピーダンスアナライザ（YHP 4192A，5 $\mathrm{Hz}$ 〜 $13 \mathrm{MHz}$ ）により実測した。容量分圧センサの BNC コネ ク夕端を測定点とし, 数 $\mathrm{MHz}$ 付近の静電容量の測定が主目 的なので,リード線のインダクタンスや容量分の補償（較 正）は $3 \mathrm{MHz}$ で行った。

測定結果を図 7 に示す。各材料ともおおむね $1 \mathrm{kHz}$ 以下 の低周波領域では, 静電容量がほほ一定なので, それぞれ この領域の值で規格化して表示した。同図より，マイカお よび PTFE の静電容量は周波数依存性が小さく, $10 \mathrm{MHz}$ ま での領域で静電容量の変化は $3 \%$ 以下である。一方, 低周 波領域での静電容量が最大であるアルミ両面蒸着の $5 \mu \mathrm{m}$ 厚 PET（No.7）は $100 \mathrm{kHz}$ 以上の高周波領域で大幅な低 下を示した。この要因として，他との著しい特性の違いか ら, 極薄 PET フィルムへのアルミ両面蒸着による, PETの 物性的変化が示唆される。したがって，前節で示したよう にステップ電圧に対しては長い減衰時定数が得られない。 このように, PET フィルムの静電容量一周波数特性に蒸着 金属の種類やその膜厚が影響することには注意が必要であ る。

PTFE は誘電体としての特性は優れているが, 静電容量 の絶対值が小さいので, 総合的にはマイカが最も優れた材 料といえる。 


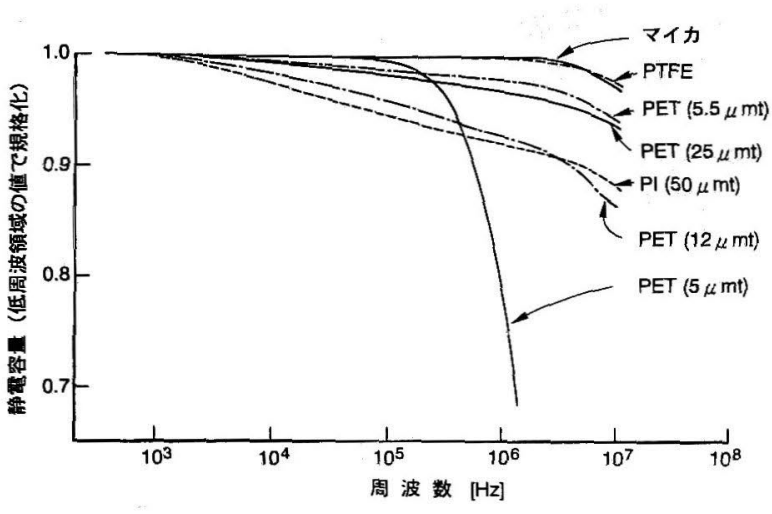

図 7 低電圧側容量の周波数特性

Fig. 7. Relationship between static capacitance and frequency of low-voltage-side capacitors.

$<4 \cdot 2>$ 低域遮断周波数の改善低電圧側容量に マイカのような静電容量が比較的大きい材料を使用して も，低域遮断周波数は $1 \mathrm{MHz}$ 程度であり，雷インパルスの 波尾などは測定できないので不便である。そこで，オシロ スコープのスカインピーダンスを $1 \mathrm{M} \Omega$ とした場合の応答 特性を検討した。

入力インピーダンスが $1 \mathrm{M} \Omega$ のオシロスコープを容量分 圧センサに接続する場合の整合回路はすでに提案例 ${ }^{(8)}$ (12) $^{(12}$ ある。ここではこれにならい, 図 8 の測定系を構成した。 図中の $\mathrm{C}_{3}$ はセンサの低電圧側容量と接続ケーブルの容量 を補償するもので，実測值 $10.61 \mathrm{nF}$ のコンデンサを使用 した。ステップ電圧の波高值やパルス幅等の条件は図 6 と 同一である。

応答波形を図 9 に示す。電圧立上り時間は1.6ns とやや 長くなるが，ステップ電圧の平坦な部分も測定できてい る。電圧立上り時間が長くなるのはオシロスコープの周波 数帯域 $(200 \mathrm{MHz})$ が低いためで,これよりも立上りがゆ るやかな電圧波形は当然測定可能である。したがって，こ の測定系でも実用上は充分な応答特性を有しており，雷イ ンパルスの波尾なども測定できるメリットは大きいと考え られる。

$\langle 4 \cdot 3\rangle$ 分圧比の周波数特性 低入力および高入 カインピーダンス測定系に対して, 容量分圧センサの分圧 比の周波数特性を EMTPで検討した。低電圧側容量材料は マイカ, またセンサへの入力電圧は正弦波とした。結果を 図10に示す。実測值と比較するため, ステップ電圧に対す る分压比を $10 \mathrm{MHz} \sim 100 \mathrm{MHz}$ 付近の領域に一点鎖線で併 記した。また, 高入力インピーダンス測定系については, 交流電圧 $(50 \mathrm{~Hz})$ に対する実測值も併記した。100MHz 以 上の高周波領域で, 破線で示した特性はオシロスコープの 周波数帯域を考慮したものである。この結果より，本セン サおよび測定系の周波数帯域を $3 \mathrm{~dB}(70 \%)$ 减衰点で定 義すると, 低入力インピーダンス測定系て $1.1 \mathrm{MHz} \sim 1$ $\mathrm{GHz}$ ，高入カインピーダンス測定系で $30 \mathrm{~Hz} \sim 200 \mathrm{MHz}$ と なる。この帯域で分圧比はほほ一定であるが, 図 7 の結果

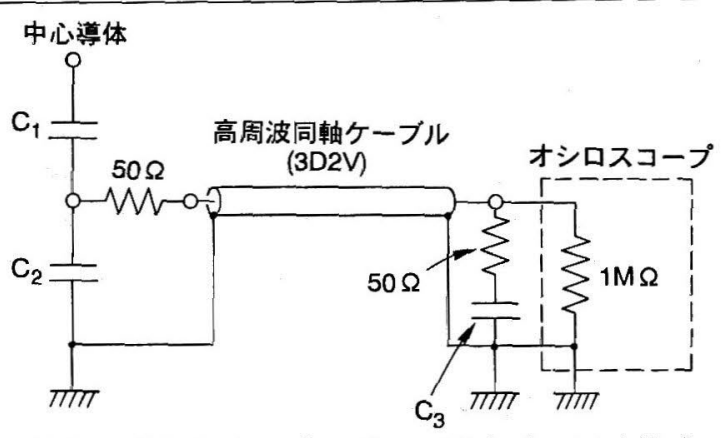

図 8 高入カインピーダンス測定系の回路褠成 Fig. 8 Diagram of the measuring system terminated with a high impedance.

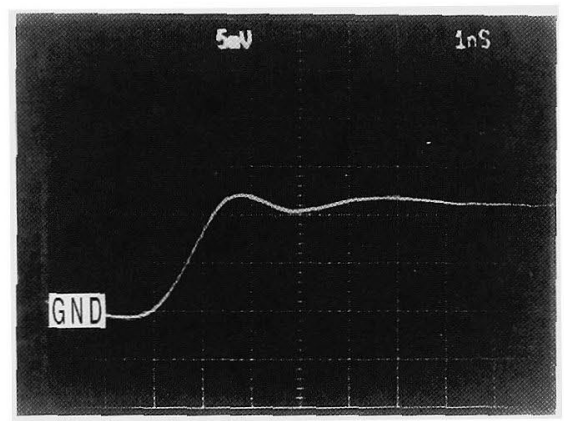

（a）電圧立上り部分（時間軸：Ins/div）

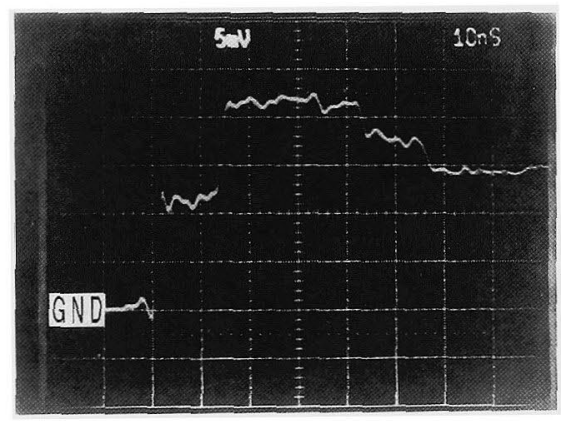

（b）波頭部分（時間軸：10ns/div）

図 9 高入力インピーダンス測定系における応答 波形（低電圧側容量材料：マイカ）

Fig. 9. Step response for the measuring system terminated with a high impedance.

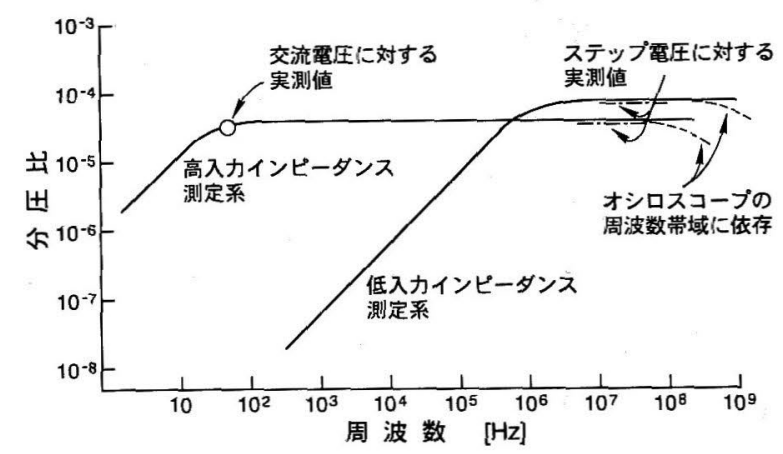

図10 容量分圧センサの分圧比一周波数特性

Fig. 10. Relationship between voltage dividing ratio and frequency of the capacitive voltage sensor. 
から， $1 \mathrm{MHz}$ 以上の高周波領域では $3 \%$ 程度の分圧比の変 動を考虑する必要がある。

なお，低域遮断周波数をさらに低減させるため，七ンサ 出力端と接続ケーブルの間に直列の高抵抗を挿入する方 法, センサ出力を FET プローブで測定する方法なども検討 したが, 前者は感度の低下, 後者はノイズの問題で有効な 方策とはならなかった。

\section{5. 実規模容量分圧センサの試作}

これまでの検討をもとに，図11に示す実規模容量分圧セ ンサを試作した。センサプレートの直径は $90 \mathrm{~mm}$ で接続ケー ブルまでの同軸構造部は, サージインピーダンスが約 $50 \Omega$ となる直径比（約 2.3 ) を維持したまま, 冈錐状の構造と した。BNCコネクタは気密構造のもので，ガス圧力が数気 圧のＧＩＳに使用することができる。低電圧側容量には而 面に銀を焼付けたマイカ（直径 $92 \mathrm{~mm}$ ）を使用した。BNC コネクタ端で測定した静電容量は $9.14 \mathrm{nF}$ であった。

本センサを $275 \mathrm{kV}$ 級 G I S 母線モデル（中心導体外径 $200 \mathrm{~mm}$ ，シース内径 $600 \mathrm{~mm}$ ）に設置して応答波形を実測 した。高電圧側ガス空間の静電容量は三次元表面電荷法に よる計算で $0.154 \mathrm{pF}$ を得た。測定系は高入力インピーダ ンスとした。既知電圧の雷インパルス扰よ゙交流電圧 （50Hz）に対して分圧比を実測すると, 雷インパルス に対しては $1 / 135000$ ，交流に対しては $1 / 139600$ とな り，両者の差は約 $3 \%$ と小さい。また, EMTP を適用して 分圧比を計算で求めると, これらの值に対し約 $4 \%$ の精度 で一致し, 本測定系の応答特性の推定に EMTP は有効な手 法である。

次に, 高気圧 $\mathrm{S} \mathrm{F}_{6}$ ガス中の球ギャップ間のフラッシオー バを利用して, 模擬的に断路器サージを発生させて, 応答 波形を実測した。GＩＳにおける実使用条件と同じく，セ ンサを設置した母線モデルにも $\mathrm{S} \mathrm{F}_{6}$ ガスを $0.5 \mathrm{MPa}$ で封 入した。結果を図 12 に示す。第 1 波の波高值は $260 \mathrm{kV}$ ， 立上り時間は $8.1 \mathrm{~ns}$ で，約 $38 \mathrm{MHz} て ゙$ 振動する波形を測定 することができた。低入力インピーダンス測定系を使用し た場合も応答波形はほほ同一であり，このような短時間領 域においては低周波電圧に対する遮断特性が問題にならな いと考えられる。

図10の例と同様に，本測定系の周波数帯域を EMTPによ り計算すると，低入力インピーダンス測定系に対して $350 \mathrm{kHz} \sim 1 \mathrm{GHz}$ ，高入カインピーダンス測定系に対して $9 \mathrm{~Hz} \sim 200 \mathrm{MHz}$ と評価された。本容量分圧センサおよび 測定系は, 実機器と同様の条件で数 $100 \mathrm{kV}$ オーダの急峻 波高電圧を測定できたことから，充分な実用性を備えたも のであると評価できる。

\section{6. まとめ}

GIS の断路器サージなどの急峻波サージ電圧を精度良 く測定できるセンサの開発を目的として, 容量分圧センサ を試作し，その応答特性を検討した。主要な結果を以下に

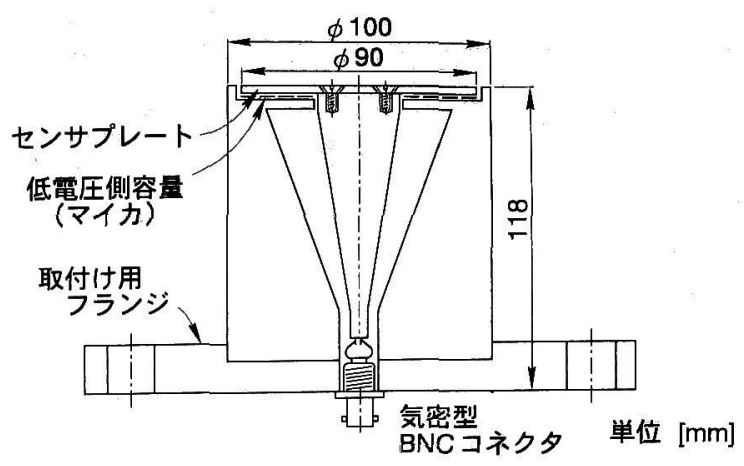

図11 実規模容量分圧センサの構造 Fig. 11. Structure of a practical-scale capacitive voltage sensor.

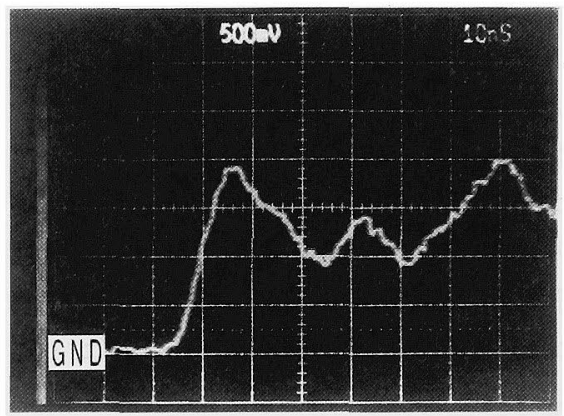

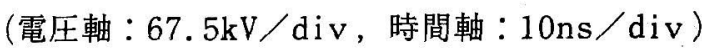

図 12 模擬断路器サージに対する応答波形

Fig. 12. Response waveform for a simulated disconnector-induced surge measured by the practical-scale sensor.

整理する。

（1）低電圧側容量材料として材質，厚さの異なる 7 種類の誘電体を検討し，いくつかの材料は静電容量が周 波数によって変化するため, 不適当であることを示し た。

（2）低電圧側容量材料として提案した銀を焼付けた マイカは静電容量が大きく, 高周波領域でも静電容量の 減衰が小さいので，本用途に適切な材料である。

（3）測定系の入カインピーダンスにより，周波数帯 域が大幅に変化するが，実測と EMTPによる解析を援用 して, 測定電圧の周波数と分圧比の関係を定量的に評価 した。

（4）低入カインピーダンス測定系では, 周波数が1 $\mathrm{GHz}$ 程度までの急峻波サージ電圧を測定できるが，数 $100 \mathrm{kHz}$ 以下の周波数成分は測定できない。一方, 高入 カインピーダンス測定系では, 周波数帯域の上限は $200 \mathrm{MHz}$ 程度であるが, 商用周波数の領域までほほ一定 の分圧比を得ることができた。

（5）実規模の容量分圧センサを試作し，実機器と同 様の条件にて数 $100 \mathrm{kV}$ オーダの模擬断路器サージを実測 した。 
本研究で使用した銀焼付けマイカ，蒸着フィルムの制作 にあたっては，双信電機(株) E MC 技術部 井上勝夫氏， 松下電器産業 (株) 飯島康男氏（現在，松江松下電器 (株)），本州製紙(株)特殊紙研究室 山内庸立氏に御高配 睗りました。また種々御指導，御協力いただいた当所狛 江研究所 鈴木俊男副所長, 環境推進室 笹野隆生次長, 電 気物理部 本山英器担当研究員, 芝浦工業大学卒論生 鈴木 康之氏（現在，東京電力）に厚く感謝の意を表します。

(平成 5 年 5 月 25 日受付)

\section{文 献}

（1）電気協同研究会：「絶縁設計の合理化」，電気協同研 究, 第44巻, 第 3 号 (昭63-12)

（2）電気学会：「急しゅん波サージとGISの絶縁問題」, 電気学会技術報告（II）部, 第324号（平2-2）

(3) W. Boeck, W. Taschner, J. Gorablenkow, G.F, Luxa \& L. Menten : "Insulating Behavior of $\mathrm{SF}_{6}$ with and without Solid Insulation in Case of Fast Transients", CIGRE Paper, No.15-07 (1986-8,9)

(4) S. Matsumoto, H. Aoyagi, H. Okubo \& Y. Kawaguchi : "Breakdown Phenomena of $\mathrm{SF}_{6}$ Gas under Fast Oscillating Impulse Voltages", Proc. of the 9th Int. Conf. on Gas Discharges and their Applications, pp.327-330 (1988-9)

(5) G. Riquel, Z.Y. Ren \& L. Lefrancois : "Comparison between V.F.T. and Lightning Impulse Breakdown Voltages for GIS Insulation in Presence of Deffects on LiveConductors", 6th Int. Symp. on High Voltage Engineering, $23.09(1989-8,9)$

（6）八島政史·藤波秀雄·宅間 董：「振動性急峻波インパ ルスに対するGISの絶緣特性(その 1)」，電力中央 研究所報告 T90052 (平3-5) および同(その2) T91024 (平4-3)

(7) S.A. Boggs \& N. Fujimoto : "Techniques and Instrumentation for Measurement of Transients in Gas-Insulated Switchgear", IEEE Trans. on Electrical Insulation, EI19, No.2, pp.87-92 (1984-4)

（8）村瀬 洋·大久保 仁·青柳浩邦·柳父 悟：「GI S 用 $1 \mathrm{GHz}$ 急しゅん波サージセンサの開発」，電学論 $B, 109,32 \sim 38$ (平元 -1 )

（9）仲西幸一郎·広兼舁一加藤賢治·井波 絜：「GＩＳ
母線モデルの急峻波 $V-t$ 特性」, 電気学会放電研究 会資料, ED-89-43（平元-5）

(10) M. Cojan : "Measurement of Fast Transient Overvoltages in GIS", CIGRE SC33 TYO-COL 06.04 (1987-10)

(11) A. Cattaneo, F. Cremonesi \& G. Rizzi : "Measurement of Overvoltages during Disconnecting of Capacitive Currents", 5th Int. Symp. on High Voltage Engineering, 12.02 (1987-8)

(12) J. Meppelink \& P. Hofer : "Design and Calibration of a High Voltage Divider for Measurement of Very Fast Transients in Gas Insulated Switchgear", ibid, 71.08 (1987-8)

(13) D.A. Bradley : "A Voltage Sensor for Measurement of GIS Fast Transients", 6th Int. Symp. on High Voltage Engineering, $49.01(1989-8,9)$

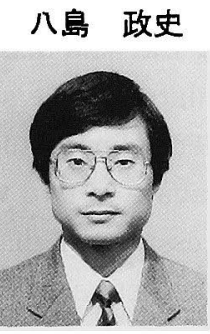

（正員）1959年 1 月24日生まれ。83年九州 大学大学院総合理工学研究科エネルギー変 換工学専攻修士課程修了。同年(財)電力中 央研究所入所。92年〜93年カナダ・マニト バ大学客員研究貝。主としてガス絶縁機器 の絶緑技術に関する研究に従事。89年電気 学会論文賞。IEEE 会員。

藤波 秀雄 (正員) 1952年12月 2 日生まれ。78年成蹊

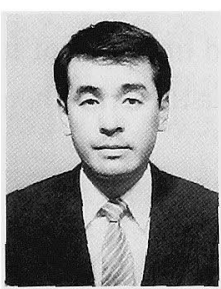
大学大学院工学研究科電気工学裏攻修士課 程修了。同年(財)電力中央研究所入所。92 年より中央電力協議会へ出向。 89 年 90 年 カナダ・マニトバ大学客員研究員。主とし てガス絶縁機器の絶縁技術に関する研究に 従事。89年電気学会論文賞。IEEE 会員。

宅間 董 (正員) 1938年9月30日生まれ。66年東京 大学大学院工学研究科電気工学専攻博士課 程修了。工学博士。同年同大学電気工学科 講師。67年 (財) 電力中央研究所入所。現 在, 同所参事。89年 93年九州大学客員教 授。75年イギリス電気学会 Maxwel1 賞, 71 年および89年電気学会論文賞, 81 年および 91年同著作賞, 92年同業繢賞。IEEE Fellow。 